\title{
Degradation of Somatomedin A by Various Organ Homogenates from Rats
}

\author{
Kolchi KAWAI ${ }^{1)}$, KazUe TAKANO, NaOMi HIZUKA \\ AND KaZUo SHIZUME \\ Department of Internal Medicine, Tokyo Women's Medical College, \\ Shinjuku-ku, Tokyo 162, Japan
}

\begin{abstract}
Synopsis
Degradative activities of somatomedin A (SMA) have been examined in various tissue homogenates of rats using trichloracetic acid precipitable radioactivity of ${ }^{125}$ ISMA. Kidney and testis showed higher specific activities and liver and brain lower activities. They were dependent on $\mathrm{SH}$ reagents; $0.5 \mathrm{mM} \mathrm{HgCl}_{2}$ inhibited the degradative activity of liver completely and $1 \mathrm{mM}$ dithiothreitol (DTT) augmented the activity slightly. The activities in liver were separated by differential centrifugation; about 90 per cent of the total activity in the whole homogenate was recovered in the supernatant fraction at $100,000 \times g$ for $60 \mathrm{~min}$, and $10 \mathrm{per}$ cent in the precipitate. The $\mathrm{pH}$ profile of each fraction was different; that of the supernatant showed a single peak at $\mathrm{pH} 7.4$ and that of the pellet revealed two peaks at $\mathrm{pH} 5.9$ and 7.4. However, both fractions showed similar SH-dependency.
\end{abstract}

Somatomedin is a second messenger which mediates the signal by growth hormone. We have examined the SMA concentration in various tissues of the rat (Kawai et al., submitted) and the time course of distribution to tissues of ${ }^{125} \mathrm{I}$ somatomedin A injected in the rat (Kawai et al., submitted). From these, it was recognized that SMA in tissues rapidly degraded in contrast to that in serum. D'Ercole et al. (1977) have reported that somatomedin C degradative activity is detected in various tissues from rats and two kinds of activities which are competitively inhibited by insulin are recognized in kidney. It has been also demonstrated that insulin degradative activities in liver homogenate as well as liver cell membranes are competitively inhibited by nonsuppres-

Received December 5, 1978.

1) Requests for reprints to No. 605 . sible insulin-like activity (NSILA-S) (Kahn et al., 1976; Burghen et al., 1976). However, the kinetic study of the SMA degradative enzyme has not been reported.

The following characterization about the SMA degradative enzymes in rat tissues was undertaken; (1) to inhibit the degradative activities for studying the SMA in tissues; (2) to assess the contribution of each organ to the degradation of ${ }^{125} \mathrm{I}-\mathrm{SMA}$; (3) to study the subcellular localization of these degradative activities and their enzymatic properties.

\section{Materials and Methods}

Male Wistar rats (200-250 g) fed ad libitum were used for all enzyme preparations. Purified SMA was gifted by Dr. L. Fryklund at Recip Polypeptide Laboratory, AB Kabi, Stockholm and identical with that used in a previous study (Takano et al., 1976). SMA was labeled by the peroxidase method and 
separated by ion exchange column chromatography with a specific activity of $30-40 \mu \mathrm{Ci} / \mu \mathrm{g}$ (Thorell et al., 1911). Trypsin inhibitor (soybean T-9378) and bovine serum albumin (BSA) (fraction V) were purchased from Sigma Chemical Company. Dithiothreitol was obtained from Nakarai Chemicals. All other chemicals were reagent grade.

Preparation of tissue homogenates and cell fractionation

Animals were perfused with $0.9 \%$ saline from the inferior caval vein, then organs were removed and homogenized in 5 vol. of $0.25 \mathrm{M}$ sucrose with a Polytolon (Brinkman, PT-10). These homogenates were diluted appropriately with $0.25 \mathrm{M}$ sucrose and used as crude enzyme sources. Liver homogenate was centrifuged at $100,000 \times g$ for $60 \mathrm{~min}$ at $4^{\circ} \mathrm{C}$. The pellet was rinsed with $0.25 \mathrm{M}$ sucrose and centrifuged again. This washing procedure was repeated and the final pellet was suspended in an initial volume of $0.25 \mathrm{M}$ sucrose. These fractions were also used as enzyme sources.

\section{Method of assay for SMA degradation}

Unless otherwise specified, the enzymatic assay was carried out according to the following method; the incubation mixture contained the tissue homogenate or subcellular fraction, $35 \mathrm{~mm}$ tris buffer, $\mathrm{pH}$ $7.4,1 \% \mathrm{BSA}$ and labeled SMA. The total volume $0.6 \mathrm{~m} l$. The assay was started by the addition of $0.2 \mathrm{nM}{ }^{125}$ I-SMA. The control tube was kept icecold. After completion of incubation at $37^{\circ} \mathrm{C}$ for $5 \mathrm{~min}, 0.4 \mathrm{ml}$ of $20 \%$ trichloracetic acid (TCA) was added. The mixture was allowed to stand for $1 \mathrm{hr}$ at $0^{\circ} \mathrm{C}$ and then centrifuged at $1,150 \times g$ for $10 \mathrm{~min}$ at $4^{\circ} \mathrm{C}$. The resultant supernate was poured off and the radioactivity of the precipitate was measured in a gamma spectrometer (Aloka). When the specific activity of the degradative enzyme in tissues was determined, the homogenate or its subcellular fraction was incubated at $37^{\circ} \mathrm{C}$ for $1 \mathrm{hr}$ to degrade the endogenous SMA and $100 \mathrm{ng}$ SMA was added in each incubation mixture. Assuming that both labeled and unlabeled SMA were degraded at the same rate, the specific activity was expressed as picomoles of SMA degraded per 5 min per $\mathrm{mg}$ of protein. Determination of protein in the homogenate and subcellular fractions was done by the method of Lowry et al. (1951).

\section{Column chromatography}

${ }^{125}$ I-SMA, which was incubated at room temperature for $1 \mathrm{hr}$ with the $100,000 \times g$ supernate of liver homogenate filtered with glass wool in the presence or absence of $0.5 \mathrm{mM} \mathrm{HgCl}_{2}$, was chromatographed at room temperatures on Sephadex G-50 (Pharmacia, $1 \times 30 \mathrm{~cm}), 0.05 \mathrm{~m}$ tris buffer, $\mathrm{pH} 7.4$. Fractions of $1.0 \mathrm{~m} l$ were collected and a portion of each frac- tion was counted in a gamma counter. Another was measured with a spectrophotometer at $280 \mathrm{~nm}$ for protein determination.

\section{Results}

When the ${ }^{125}$ I-SMA was incubated with liver homogenate, the radioactivity of the TCA-soluble fraction increased with the incubation period. The time course curved convexly. The reaction rate slowed down after $5 \mathrm{~min}$ (Fig. 1). Similar time course patterns were obtained with other tissue homogenates. Because of these results, incubation was usually performed for $5 \mathrm{~min}$.

The following experiment was undertaken to determine whether this decrease of the TCA-precipitable radioactivity was derived from a proteolytic reaction. ${ }^{125}$ I-

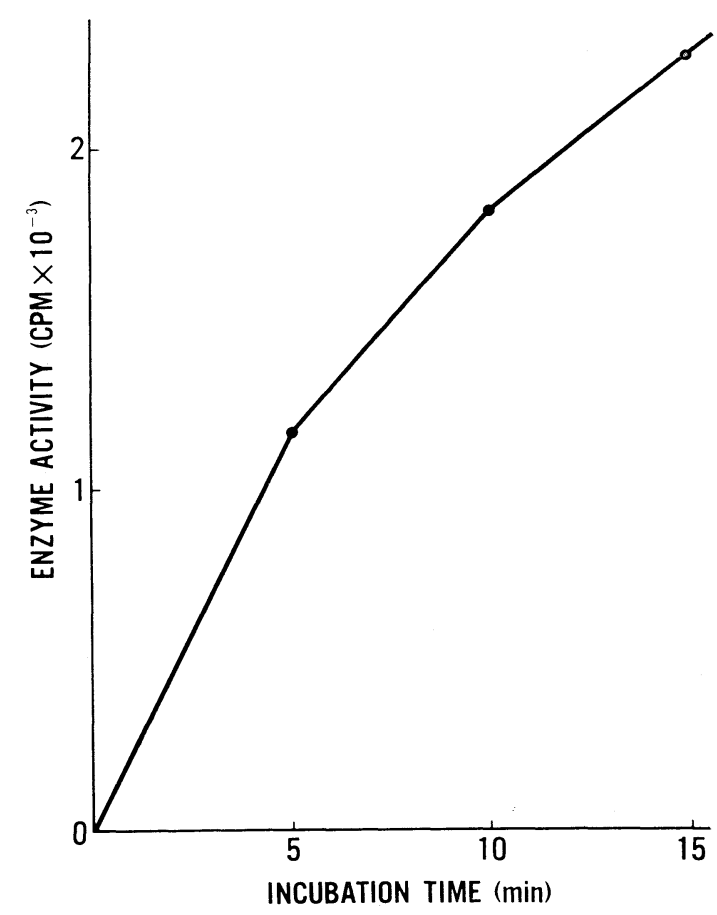

Fig. 1. The time course of SMA degradation by liver homogenate. The assay mixture was incubated at $37^{\circ} \mathrm{C}$ for each period and the radioactivity of TCA-precipitate was measured. Each point is the average value of three experiments. 


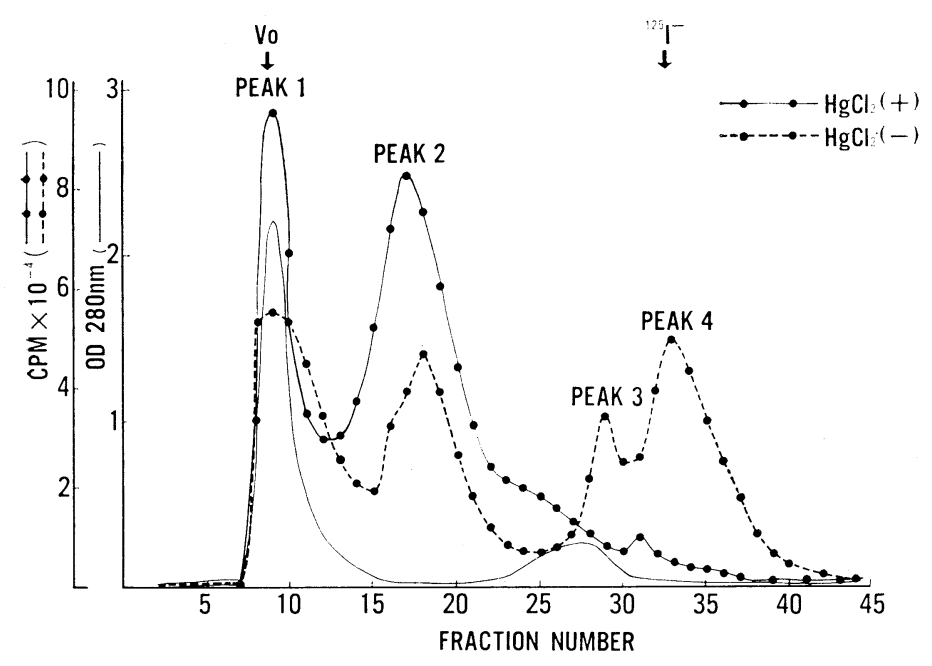

Fig. 2. Sephadex G-50 elution pattern of ${ }^{125} \mathrm{I}-\mathrm{SMA}$ incubated with the $100,000 \times g$ supernate of liver homogenate. The detail experimental procedures were described in Materials and Methods. Arrows indicate the position of void volume (Vo) and that of ${ }^{125} \mathrm{I}^{-}$eluted $\left({ }^{125} \mathrm{I}^{-}\right)$. - indicates the radioactivity profile when ${ }^{125}$ I-SMA was incubated in the presence of $0.5 \mathrm{~mm} \quad \mathrm{HgCl}_{2}$ and .......... in the absence of $\mathrm{HgCl}_{2}$. - shows the profile of optical density at $280 \mathrm{~nm}$. Two experiments gave indentical results.
SMA was incubated with liver homogenate in the presence or absence of $0.5 \mathrm{mM} \mathrm{HgCl}_{2}$ at room temperature and chromatographed on Sephadex G-50 (Fig. 2). In the absence of $\mathrm{HgCl}_{2}$, which is an inhibitor of SMA degradative activity in liver (Kawai et al., submitted), the largest amount of the radioactivity was recovered in the peak 4 where ${ }^{125} \mathrm{I}^{-}$was eluted and the radioactivity of peak 1 and 2 decreased following the increase in that of peak 3 and 4 . By calculating the elution coefficient, peak 1 and peak 2 were identified as the ${ }^{125}$ I-SMA bound to the binding proteins and the free ${ }^{125}$ I-SMA, respectively. Peak 3 consisted of degradative products of the ${ }^{125}$ I-SMA.

When different amounts of the liver homogenate were incubated with ${ }^{125}$ I-SMA, the enzyme activity did not increase proportionally with the amount of enzyme (Fig. 3). From this result, in order to calculate the degradative rate of SMA by each organ, a proper dilution of the homogenate from each organ was selected so that the rate of degradation for the first 5 min followed first-order kinetics. In these circumstances, the SMA degradative activities in various tissue homogenates were

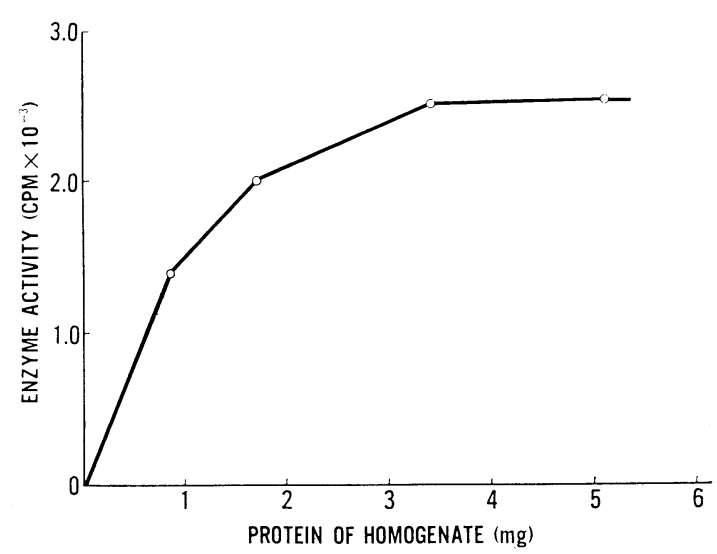

Fig. 3. The relationship of SMA degradation to concentration of liver homogenate. The amount of liver homogenate in assay mixture was changed and expressed as protein content of the homogenate added. The assay mixture consisted of $1 \mathrm{~m} l$ in this case. Each point is the average value of three experiments. 
examined and the rate of degradation was calculated per $5 \mathrm{~min}$ per $\mathrm{mg}$ protein of homogenates (Table 1). The order for SMA degradation from the most to the least active organ is kidney, testis, lung, pancreas, muscle, brain and liver.

As it has been suggested that somatomedin is generated in liver (McConaghey, 1972; Phillips et al., 1976) and liver is one of the chief metabolic pools of SMA (Kawai et al., submitted), the characteristics of the degradative activity of liver were examined. The activity of liver homogenate was decreased by $65 \%$ after the treatment at $37^{\circ} \mathrm{C}$ for $1 \mathrm{hr}$ and $80 \%$ after $60^{\circ} \mathrm{C}$ for $5 \mathrm{~min}$. Freezing and thawing abolished $15 \%$ of the initial activity.

The effects of various compounds on the SMA degradative activities were examined (Table 2). The activity in liver was inhibited by $0.5 \mathrm{~mm} \mathrm{HgCl}_{2}$ and stimulated by $1 \mathrm{~mm}$ DTT. EDTA reduced the degradative activity slightly. Table 2 also demonstrates the lack of the effect of serine protease inhibitor on the enzyme activities. There were no clear differences in results about the degradative activities in lung, kidney and liver.

The localization of degradative activity in liver was examined with differential centrifugation (Table 3). The first 100,000 $\times g$ supernate contained the greater part of degradative activity and demonstrated higher specific activity. This fraction, therefore, is the probable source of the enzyme responsible for SMA catabolism in the intact liver. The pellet was washed twice. The final pellet contained only 10 $\%$ of the activity in the whole homogenate and showed a very low specific activity. The effects of $\mathrm{SH}$ reagents on the first supernate and the final pellet were shown in Table 4. No remarkable differences were recognized; $\mathrm{HgCl}_{2}$ inhibited and DTT activated both fractions, though it stimulated the activity in the pellet more.

The variation of enzymatic activity with
Table 1. SMA degradation by homogenates from various tissues of rats.

\begin{tabular}{lc}
\hline Tissue & $\begin{array}{c}\text { Specific activity of SMA degradation* } \\
\text { (picomoles SMA destroyed in } \\
5 \mathrm{~min} / \mathrm{mg} \text { protein) }\end{array}$ \\
\hline Brain & 0.48 \\
Lung & 0.87 \\
Liver & 0.33 \\
Pancreas & 0.74 \\
Kidney & 1.36 \\
Testis & 1.08 \\
Muscle & 0.50
\end{tabular}

The homogenates were treated for $1 \mathrm{hr}$ at $37^{\circ} \mathrm{C}$ in order to diminish endogenous SMA in homogenates. Then, adequately diluted homogenate was added to incubation mixture and SMA degradation was measured as described in Materials and Methods.

* Average values of three separate experiments.

Table 2. Effects of various substances on SMA degradative activities.

\begin{tabular}{lrcr}
\hline \hline \multirow{2}{*}{$\begin{array}{c}\text { Substances } \\
\text { added }\end{array}$} & $\begin{array}{c}\text { Relative activity } \\
\text { homo- } \\
\text { genate }\end{array}$ & $\begin{array}{l}\text { Kidney } \\
\text { homo- } \\
\text { genate }\end{array}$ & $\begin{array}{c}\text { Liver } \\
\text { homo- } \\
\text { genate }\end{array}$ \\
\hline Control & 100 & 100 & 100 \\
$3 \mathrm{mM}$ EDTA & 77 & 73 & 94 \\
$1 \mathrm{mM}$ Dithiotheitol & 125 & 116 & 143 \\
$1 \mathrm{~mm}$ Glutathione & 82 & 80 & 94 \\
$0.5 \mathrm{~mm} \mathrm{HgCl}$ & 0 & 59 & 0 \\
Soybean trypsin & & & \\
$\quad$ inhibitor $(200 \mu \mathrm{g} / \mathrm{ml})$ & 86 & 94 & 100 \\
\hline
\end{tabular}

* Average values of two separate experiments.

Table 3. SMA degradation by fractions of liver homogenate.

\begin{tabular}{|c|c|c|c|c|c|}
\hline Fractions & $\mathrm{m} l$ & $\begin{array}{l}\text { Activity } \\
\text { (pico- } \\
\text { moles } \\
\text { SMA de- } \\
\text { stroyed in } \\
5 \mathrm{~min} / \mathrm{ml}\end{array}$ & $\begin{array}{l}\text { Protein } \\
(\mathrm{mg} / \mathrm{ml})\end{array}$ & $\begin{array}{l}\text { Specific } \\
\text { Activity } \\
\text { (pico- } \\
\text { moles } \\
\text { SMA de- } \\
\text { stroyed in } \\
5 \mathrm{~min} / \mathrm{m} l \text { ) }\end{array}$ & $\begin{array}{l}\text { Yield } \\
(\%)\end{array}$ \\
\hline (whole) & 15.0 & 12.0 & 40.0 & 0.30 & 100 \\
\hline Supernrte-1 & 12.5 & 11.8 & 15.0 & 0.79 & 82.6 \\
\hline Supernate-2 & 4.0 & 6.38 & 5.58 & 1.14 & 14.2 \\
\hline Supernate-3 & 4.0 & 2.42 & 2.89 & 0.84 & 5.4 \\
\hline Pellet & 5.0 & 3.73 & 38.5 & 0.10 & 10.4 \\
\hline
\end{tabular}

Experimental procedures were performed as described in Materials and Methods. The supernate-1 is the supernatant fraction of the initial centrifugation at $100,000 \times g$ for $60 \mathrm{~min}$. The supernate- 2 and -3 are the supernates of the twice washing procedures. The pellet is the precipitate of the final centrifugation. 
Table 4. Effects of various substrates on SMA degradative activities in the liver supernate and pellet.

\begin{tabular}{lcc}
\hline & \multicolumn{2}{c}{ Relative } \\
\cline { 2 - 3 } $\begin{array}{c}\text { Substances } \\
\text { added }\end{array}$ & $\begin{array}{c}\text { Liver } \\
\text { pellet }\end{array}$ & $\begin{array}{c}\text { Liver } \\
\text { supernate }\end{array}$ \\
\hline Control & 100 & 100 \\
$1 \mathrm{mM} \mathrm{N}-E$ thylmaleimide & 118 & 102 \\
$0.5 \mathrm{mM} \mathrm{HgCl}_{2}$ & 0 & 0 \\
$1 \mathrm{mM} \mathrm{Dithiothreitol}$ & 156 & 125 \\
$1 \mathrm{mM}$ Glutathione & 103 & 89 \\
\hline
\end{tabular}

* Average values of two separate experiments.

$\mathrm{pH}$ was examined with the whole liver homogenate, the $100,000 \times g$ supernate and the pellet (Fig. 4). The maximal activity for the supernate was obtained at $\mathrm{pH}$ 7.4. The pellet showed two peaks of activity at $\mathrm{pH} 5.9$ and $\mathrm{pH}$ 7.4. The effect of differing buffer reagents on the degradative activity was negligible. The whole homogenate showed a $\mathrm{pH}$ profile comparable to the summation of two components.

Assuming that the labeled and unlabeled SMA degraded at the same rate, the velocity of degradation by the whole liver homogenate was plotted by the method of Lineweaver and Burk (1934). The $\mathrm{km}$ value obtained was $0.9 \times 10^{-8} \mathrm{M}$ (Fig. 5).

\section{Discussion}

In this paper we demonstrate the SMA degradative activities in rat tissues. Hydrolytic cleavage of SMA was suggested from the result that SMA in tissue homogenates decreased during the incubation at $37^{\circ} \mathrm{C}$ (Kawai et al., submitted) and the result in Fig. 2.

Precipitability by TCA is a simple technique for measuring intact ${ }^{125} \mathbf{I}$ or ${ }^{131} \mathbf{I}$ polypeptide hormones and it has been widely used by previous investigators to study degradation of ${ }^{125} \mathrm{I}$ or ${ }^{131}$ I-insulin in vitro (Tamizawa et al., 1955; Brush, 1971 ; Burgen et al., 1972; Duckworth et al., 1972; Kahn et al., 1976). However, the

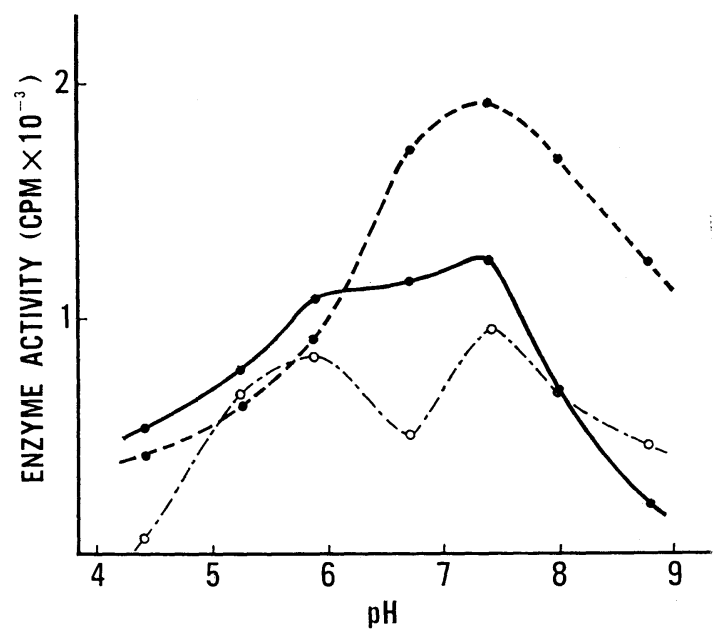

Fig. 4. $\mathrm{pH}$ profile of SMA degradative activities in liver homogenate; whole homogenate (- - $), 100,000 \times g$ supernatant $(\cdots \cdots \cdot \cdots \cdots \cdot \cdots \cdot$, $100,000 \times g$ pellet (-.-O-.-O-.-). Enzymatic activity at each $\mathrm{pH}$ was determined using $70 \mathrm{mM}$ acetate buffer ( $\mathrm{pH} 4.4$ and 5.2), $70 \mathrm{mM}$ phosphate buffer (pH 6.0, 6.8 and 7.4) and $70 \mathrm{~mm}$ tris buffer $\mathrm{pH} 8.0$ and 8.8). Each curve is the average of two separete experiments.

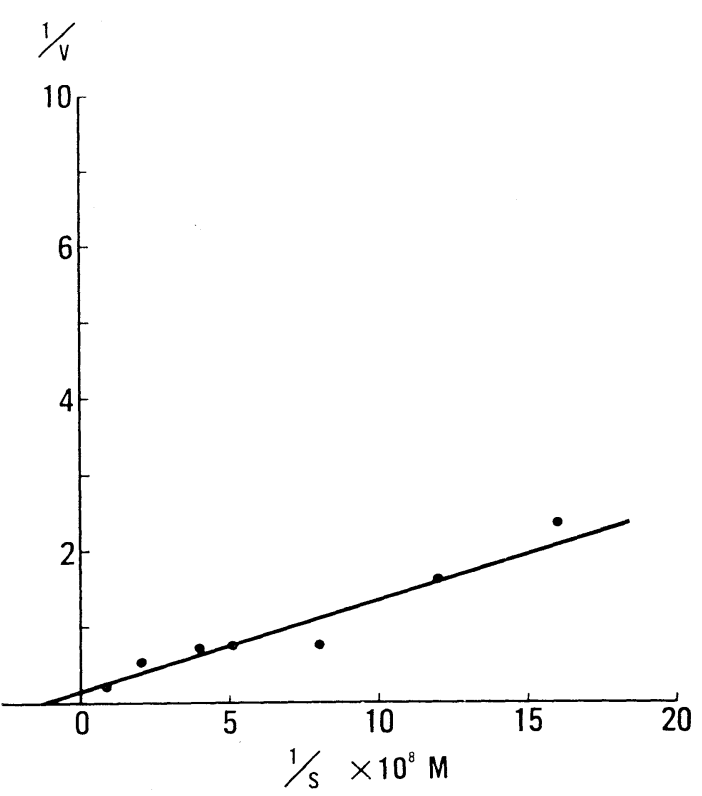

Fig. 5. Double reciprocal plots of SMA degradation by the whole homogenate of liver. The experimental procedure was described in Materials and Methods. 
validity of the method for studying the kinetics of degradation of ${ }^{131}$ I-insulin in vitro has been discussed (Izzo et al., 1972). The convex pattern of enzyme activity with an increasing incubation period and with an increasing amount of the homogenate might be partly explained by the faults of this method. It has been reported that the apparent enzymatic activity decreases more with an increasing incubation period when ${ }^{125}$ I-insulin degradative activity in liver plasma membrane is measured with precipitation by TCA than when it is measured by binding to the anti-insulin antibody (Freychet et al., 1972). Tomizawa (1962) has demonstrated that the A chain of insulin is not precipitated by $5 \%$ TCA. These might that smaller proteolytic peptides of smaller weight than a critical molecular weight are not precipitated by TCA, so that degradative activity appears to decrease in the later incubation period. Another problem with this method is that some modification of polypeptide structure by iodination is probable. It is possible that the 125I-SMA molecule becomes more labile or stable to enzymatic degradation, though the specific activity was calculated under the assumption that both labeled and unlabeled SMA were degraded at the same rate in this experiment. It has been reported that the rate and extent of degradation of ${ }^{131} \mathrm{I}$ insulin are inversely proportional to the amount of iodine attached to the hormone (Izzo et al., 1972). However, the heat labile nature of this degradative activity and the relatively deficient substrate concentration also explain the convex pattern. Moreover, the possibility that inhibitors of enzyme action also increase as protein concentration increases can not be ruled out (Dixon and Webb, 1958).

The specific activities of SMA degradative enzymes in tissue homogenates showed almost the same values described for somatomedin C degradative activities (D'Ercole et al., 1977). In the case of insulin degradative activities in tissue homogenates, the hierarchy of active organs is quite different (Kitabuchi et al., 1972). The order of the most to the least active organ in liver, pancreas, testis, kidney, lung and brain in the case of insulin degradative activity.

SMA degradative activity was dependent on SH reagents and indepenent of trypsin inhibitors. Insulin specific proteases in cytosol and plasma membrane and somatomedin $\mathrm{C}$ degradative activities are also dependent on SH reagents (Freychet et al., 1972; Duckworth et al,, 1972; D'Ercole et al., 1977). In each case, DTT activates enzyme activity and $p$-hydroxymercuribenzoate and $\mathrm{HgCl}_{2}$ inhibit it. But the degree of activation by DTT, gluthathione and 2mercaptoethanol differs from report to report. This might be attributed to endogenous $\mathrm{SH}$ compounds in tissue homogenates.

About $90 \%$ of the SMA degradative activity in liver was found in the cytosol fraction and it exhibited much higher specific activity than that of the membrane fraction, although both activities were dependent on $\mathrm{SH}$ reagents. Their $\mathrm{pH}$ profiles were different and the recombination of both fractions showed an additive $\mathrm{pH}$ profile (data not shown). This suggests that the activity in cytosol does not change its character with attachment to the membrane. It has been reported that the $100,000 \times g$ supernatant is responsible for $96 \%$ of the total insulin degrading activity (Curghen et al., 1972) and this activity, as well as the activity in microsomal fraction, is SH-dependent. On the other hand, $70 \%$ of somatomedin $\mathrm{C}$ degrading activity in kidney is found in particulate fraction and $30 \%$ is found in cytosol fraction (D'Ercole et al., 1977). The activity in cytosol is more activated by DTT than that in particulate fraction.

The physiological significance of this degradative activity is not clarified from the above data. It has not been determined whether this degradative activity is 
derived from the specific protease for SMA. It might originate in insulin specific protease. The characteristics of SMA degradative activity in liver closely resemble those of insulin specific protease in several points such as SH dependency, cellular localization, $\mathrm{pH}$ profile, heat lability and $\mathrm{Km}$. We have reported that ${ }^{125} \mathrm{I}-\mathrm{SMA}$ accumulates in all tissues examined and is degraded there. Kidney is a main organ for these procedures (Kawai et al., submitted). Although the role of the SMA incorporated into cells has not been examined yet, it is likely that SMA in liver controls insulin degradation. Insulin degradative activity in liver homogenate is competitively inhibited by NSILA-S (Brurghen et al., 1976).

\section{Acknowledgements}

The authors are greatly indebted to Doctors Linda Fryklund and Hans Sievertsson from the Research Department of AB KABI, Stockholm, who purified and supplied us with the somatomedin A preparations used. This report was partly supported by the Research Grant from Foundation for Growth Science (Japan). We are grateful to Miss M. Shiota for her technical assistance.

\section{References}

Burghen, G. A., A. E. Kitabchi and J. S. Brush (1972). Endocrinology 91, 633.

Burghen, G. A., W. C. Duckworth, A. E. Kitaguchi, S. S. Solomon and P. L. Poffenbarger (1976). J. Clin. Invest. 57, 1089.

Brush, J. S. (1971). Diabetes 20, 140.

D'Ercole, A. J., C. J. Decedue, R. W. Furlanetto, L. E. Underwood and J. J. Van Wyk (1977). Endocrinology 101, 577.

Dixon, M. and E. C. Webb. Enzymes, pp. 69 Academic Press, New York (1958).

Duckworth, W. C., M. A. Heinemann and A. E. Kitabchi (1972). Proc. Nat. Acad. Sci. USA 69, 3698.

Freychet, P., C. R. Kahn, J. Roth and D. M. Neville, Jr. (1972). J. Biol. Chem. 247, 3953.

Izzo, J. L., A. Roncone, M. J. Izzo, R. Foley and J. W. Bartlett (1972). Ibid. 247, 1219.

Kahn, C. R., K. Megyesi and J. Roth (1976). J. Clin. Invest. 57, 526.

Kitabchi, A. E., F. B. Stentz and M. A. Bobal (1972). Diabetes 21, 1091.

Lineweaver, H. and D. Burk (1934). J. Amer. Chem. Soc. 56, 658.

Lowry, O. H., N. J. Rosebrough, A. L. Farr and R. J. Randall (1951), J. Biol. Chem. 193, 265.

McConaghey, P. (1972). J. Endocrinol. 52, 1.

Phillips, L. S., A. C. Herington, I. E. Karl and W. H. Daughaday (1976). Endocrinology 98, 606.

Takano, K., K. Hall, M. Ritzen, L. Iselius and H. Sievertsson (1976). Acta Endocrinol. $(K b h)$ 82, 16.

Thorell, J. I. and B. G. Johansson (1971). Biochim. Biophys. Acta 251, 363.

Tomizawa, H. H., M. L. Nutley, H. T. Narahara and R. H. Williams (1955). J. Biol. Chem. 214, 285.

Tomizawa, H. H. (1962). Ibid. 237, 428. 